\section{In utero sister chromatid exchange analysis for detection of transplacental mutagens}

FETAL exposure to agents which damage DNA can result in birth anomalies, cancer and inherited abnormalities. In the present report we describe a new approach for the detection of fetal DNA damage through the enumeration of sister chromatid exchanges (SCE) in mouse fetal chromosomes. SCE can be identified as reciprocal exchanges of fluorescent intensities betweeen sister chromatids in metaphase cells which have divided twice in the presence of bromodeoxyuride (BrdU) (Fig. 1). Analysis of SCE has been shown to be a sensitive and reproducible means of detecting chemical mutagens and carcinogens $^{1-9}$.

Differential chromatid staining of metaphase cells from maternal and fetal tissues was achieved when pregnant females were intravenously infused with BrdU for $24 \mathrm{~h}$ at gestational days 11,15 and 19. SCE frequencies were simultaneously studied in fetal cells as well as in maternal bone marrow. Baseline SCE frequencies in fetal cells were generally lower than in maternal cells, ranging from 2.4 to $3.6 \mathrm{SCE}$ per second replication cycle cell, and these values did not change significantly as a function of gestational age (Table 1, Fig. 1b).

To examine in utero SCE induction, three known mutagens (cyclophosphamide, CP; mitomycin C, MMC; adriamycin, ADM) were injected into pregnant females on day 13 of gestation (Table 1, Fig. 1a). Drug concentrations were selected which would induce similar levels of SCE for each agent in maternal cells (approximately $20 \mathrm{SCE}$ per cell ${ }^{10}$ ). These same drug doses resulted in varying levels of SCE induction in fetal cells. Cyclophosphamide administration resulted in similar SCE induction in fetal and maternal cells; MMC resulted in fetal SCE levels which were slightly lower than those in maternal cells, while fetal SCE induction with ADM was only one third that seen in maternal cells (but significantly higher than baseline levels).

The doses of CP and MMC which resulted in a 5-10-fold increase in fetal SCE were well below the teratogenic doses for these drugs ${ }^{11,12}$ while ADM, which showed the weakest induction of fetal SCE, is not teratogenic ${ }^{13}$. We therefore suggest that in utero SCE analysis should be used in addition to existing assays for screening fetal exposure to mutagens, carcinogens and teratogens which act at the level of DNA damage. In utero SCE analysis is relatively simple, rapid,

Table 1 Baseline and mutagen-induced SCE frequencies in materal and fetal cells

\begin{tabular}{cccc}
\hline $\begin{array}{c}\text { Gestational } \\
\text { day* }\end{array}$ & $\begin{array}{c}\text { Drug } \dagger \\
\text { (mg per kg) }\end{array}$ & $\begin{array}{c}\text { Bone } \\
\text { marrow } \ddagger\end{array}$ & $\begin{array}{c}\text { Embryos§ } \\
11\end{array}$ \\
15 & 0 & $4.0 \pm 0.4$ & $2.7 \pm 0.2(4)$ \\
19 & 0 & $3.2 \pm 0.4$ & $2.4 \pm 0.3(4)$ \\
& 0 & $4.8 \pm 0.5$ & $3.6 \pm 0.6(3)$ \\
13 & CP 10 & $23.4 \pm 1.1$ & $27.0 \pm 1.4(4)$ \\
$14-15$ & CP 10 & $22.0 \pm 1.4$ & $25.0 \pm 1.2(4)$ \\
13 & MMC 1 & $18.2 \pm 0.9$ & $14.2 \pm 1.1(3)$ \\
13 & MMC 1 & $21.2 \pm 1.0$ & $15.8 \pm 1.0(3)$ \\
13 & ADM 5 & $17.8 \pm 1.2$ & $6.3 \pm 0.4(4)$ \\
13 & ADM 5 & $17.6 \pm 0.9$ & $6.5 \pm 0.4(4)$ \\
\hline
\end{tabular}

* In cases where a range of days are indicated, gestational age was estimated by examination of fetuses at the time of killing.

$\dagger$ Drugs were intravenously injected in a volume of $0.1 \mathrm{ml}$.

$\ddagger$ A minimum of 25 second replication cycle bone marrow cells were analysed for each mother.

$\$$ A minimum of 10 second replication cycle cells were analysed for each fetus. Values in brackets indicate the number of fetuses analysed.
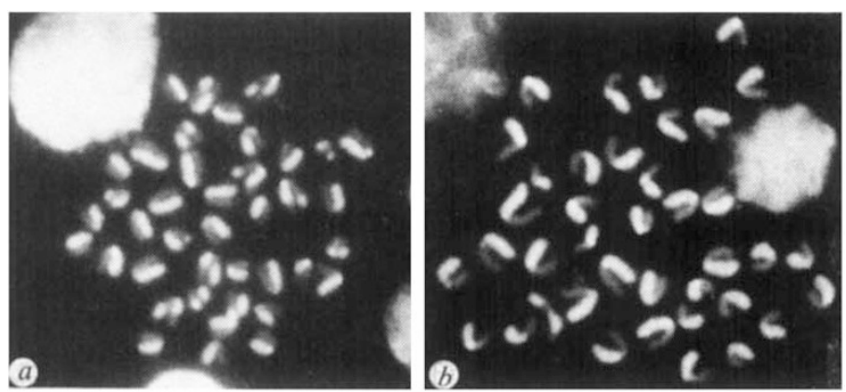

Fig. 1 Photomicrographs of mouse fetal chromosomes. $b$, Second replication cycle cell showing baseline level of SCE; $a$, second replication cycle cell showing cyclophosphamide induced level of SCE. Two to four month-old female C57BL/6J mice (Jackson) were mated with male mice of the same age and strain. Gestational age was determined by counting the number of days after observation of vaginal plugs or by examination of fetuses at the time of killing. Pregnant mice were infused according to our previously described techniques at $50 \mathrm{mg}$ per $\mathrm{kg}$ wt per h (refs 8,15 ). After $23 \mathrm{~h}$ of intravenous infusion, mice were injected with $2.5 \mu \mathrm{g}$ demecolcine (Colcemid, GIBCO) and killed $1 \mathrm{~h}$ later. Those mice treated with mutagens (CP, Mead, Johnson; MMC, Sigma; ADM, Adria Labs) were injected intravenously $1 \mathrm{~h}$ after the onset of the infusion. After killing, the entire uterus was excised and individual fetuses incubated in $0.2 \%$ collagenase (GIBCO). Vigorous pipetting in Eagle's minimal essential medium (MEM) resulted in single cell suspensions of fetal tissues. Cells were isolated from maternal bone marrow as described previously ${ }^{8,15}$. Cell suspensions were then swollen in $0.07 \mathrm{M} \mathrm{KCl}$, fixed (methanol/acetic acid, $3: 1$ ) and dropped on to glass slides. Chromosome preparations were stained with $4^{\prime}$-6-diamidino-2-phenylindole $\left(10 \mu \mathrm{g} \mathrm{ml}^{-1}\right.$, (ref. 16)) and chromosomal analyses were performed with a Zeiss photomicroscope equipped with epi-illumination.

reproducible, requires small numbers of animals, allows simultaneous examination of the effect of agents on fetal and maternal cells, and may be more sensitive than previously described techniques such as the micronucleus assay ${ }^{14}$ or measurement of chromosomal aberrations ${ }^{1}$.

\section{DAVID KRAM}

\section{GAITHER D. BYNUM}

GERHARD C. SENULA

EDWARD L. SCHNEIDER

Section on Cellular Aging and Genetics,

Laboratory of Cellular and Molecular Biology

Gerontology Research Center,

National Institute on Aging,

National Institutes of Health, PHS,

US Department of Heath, Education and Welfare,

Baltimore, Maryland 21224

Received 26 February; accepted 11 April 1979

1. Perry, P. \& Evans, H. J. Nature 258, 121-125 (1975).

2. Solomon, E. \& Bobrow, M. Mutat. Res. 30, 273-278 (1975).

3. Abe, S. \& Sasaki, M. J. natn. Cancer Inst. 58, 1635-1641 (1977).

4. Allen, J. W. \& Latt, S. A. Nalure 260, 449-451 (1976).

5. Stetka, D. G. \& Wolff, S. Mutat. Res. 41, 333-342 (1976).

6. Pera, F. \& Mattias, P. Chromosoma 57, 13-18 (1976).

7. Vogel, W. \& Bauknecht, T. Nature 260, 448-449(1976).

8. Schneider, E. L., Chaillet, J. R. \& Tice, R. R. Expl Cell Res. 100, 396-399 (1976).

9. Carrano, A. V., Thompson, L. H., Lindl, P. A. \& Minkler, J. L. Nature 270, $551-553$ (1978).

10. Nakanishi, Y. \& Schneider, E. L. Mutat. Res. (in the press)

11. Gibson, J. E. \& Becker, B. A. Cancer Res. 28, 475-480 (1968).

12. Tanimura, T. Okajimas Folia Anat. Jap. 44, 337-355 (1968)

13. Ohguro, T., Hatano, M., Imamura, T. \& Shimizu, M. Yakubutsu Ryoho (Medical Treatment) 6, 1152-1164 (1973).

14. Marquardt, H. \& Bayer, U. Mutat. Res. 56, 169-176 (1977)

15. Schneider, E. L., Tice, R. R. \& Kram, D. in Methods in Cell Biology 20, 379 (Academic, New York, 1978).

16. Lin, M. S. \& Alfi, O. S. Chromosoma 57, 219-225 (1976). 